Tropical Journal of Pharmaceutical Research May 2019; 18 (5): 1077-1081

ISSN: $1596-5996$ (print); 1596-9827 (electronic)

(C) Pharmacotherapy Group, Faculty of Pharmacy, University of Benin, Benin City, 300001 Nigeria.

\title{
Total flavones of Desmodium styracifolium antagonize calcium oxalate monohydrate-triggered IL-2R $\beta$ expression in renal epithelial cells
}

\author{
Haijie Xie, Rui Yang, Yong Xu, Chunyu Liu* \\ Urolithiasis Treatment Center of Tianjin, Tianjin Institute of Urology, The Second Hospital of Tianjin Medical University, 23 \\ Pingjiang Road, Hexi District, Tianjin 300211, China
}

*For correspondence: Email: chunyuliu2017@126.com; Tel: +86-022-88328091

Sent for review: 14 December 2018

Revised accepted: 22 April 2019

\begin{abstract}
Purpose: To explore the effect of total flavone of Desmodium styracifolium (TFDS) on calcium oxalate monohydrate (COM)-triggered IL-2Rß expression in human kidney proximal tubular epithelial cells. Methods: Human kidney proximal tubular epithelial cell line HK-2 was treated with COM, TFDS or both. The expression of IL-2R $\beta$ was evaluated by quantitative polymerase chain reaction ( $q P C R$ ) or flow cytometry. The responsiveness of HK-2 cells to IL-2 was determined by enzyme-linked immunosorbent assay (ELISA), QPCR and western blot. The signaling mechanism underlying the effect of TFDS was studied using western blot and $Q P C R$. The clinical relevance of IL-2R $\beta$ to renal inflammation was investigated by re-analyzing a Gene Expression Omnibus (GEO) dataset.

Results: Total flavones of Desmodium styracifolium (TFDS) antagonize COM-triggered IL-2R expression in HK-2 cells, thus reducing the responsiveness of HK-2 cells to IL-2 stimulation. Mechanistically, TFDS dampens IL-2R $\beta$ expression by preventing the activation of STAT3. The level of $I L-2 R \beta$ is positively correlated with the inflammatory status of the kidney.

Conclusions: The total flavones of Desmodium styracifolium (TFDS) prevent the upregulation of IL$2 R \beta$ in renal epithelial cells upon COM stimulation in a STAT3-dependent manner.
\end{abstract}

Keywords: Total flavones, Desmodium styracifolium, Calcium oxalate, Urinary calculi, IL-2Rß, STAT3 signaling

\begin{abstract}
This is an Open Access article that uses a fund-ing model which does not charge readers or their institutions for access and distributed under the terms of the Creative Commons Attribution License (http://creativecommons.org/licenses/by/4.0) and the Budapest Open Access Initiative (http://www.budapestopenaccessinitiative.org/read), which permit unrestricted use, distribution, and reproduction in any medium, provided the original work is properly credited.
\end{abstract}

Tropical Journal of Pharmaceutical Research is indexed by Science Citation Index (SciSearch), Scopus, International Pharmaceutical Abstract, Chemical Abstracts, Embase, Index Copernicus, EBSCO, African Index Medicus, JournalSeek, Journal Citation Reports/Science Edition, Directory of Open Access Journals (DOAJ), African Journal Online, Bioline International, Open-J-Gate and Pharmacy Abstracts

\section{INTRODUCTION}

Urinary calculi is a common disease with an approximate prevalence of 5 - $45 \%$ [1]. Oxalate calculi represents nearly $70-80 \%$ cases of urinary calculi [2]. In terms of etiology, calcium oxalate monohydrate (COM) leads to the damage of renal tubular epithelial cells. The adherence of calcium oxalate monohydrate crystal to the lesion site facilitates renal crystallization and the formation of urinary calculi $[3,4]$. Although various have approaches have been used in the treatment of urinary calculi such as extracorporeal shock wave lithotripsy and percutaneous nephroscope, the cellular and molecular basis of urinary calculi are still far from clear. This lack of understanding hinders further development of therapeutic strategies. 
Desmodium styracifolium, a traditional Chinese medicinal herb, is used in the treatment of various renal diseases such as kidney stone or kidney damage. Nevertheless, the detailed mechanisms of Desmodium styracifolium as a kidney stone inhibitor remain elusive. Previous studies have reported that total flavone of Desmodium styracifolium (TFDS) inhibited the formation of calcium oxalate monohydrate crystal in the kidneys of hyperoxaluria rats. This work also indicated that TFDS alleviated COMinduced apoptosis and autophagy of kidney proximal tubular epithelial cells [5]. The exact effect of TFDS on the function of renal tubular epithelial cells remains largely unknown. Nevertheless, the detailed therapeutic mechanisms of TFDS remain to be further explored. Previous reports have indicated that renal tubular epithelial cells express functional IL2 receptor which may contribute to renal disorders $[6,7]$.

\section{EXPERIMENTAL}

\section{Reagents}

Desmodium styracifolium was obtained from Xi'an Tianrui Biological Technology Company (Xi'an, China), COM crystals were prepared as previously described [5]. STAT3 inhibitor S3I-201 was purchased from Selleck (Houston, USA), p38 inhibitor SB203580 was purchased from Beyotime (Shanghai, China). Human IL-2 was purchased from Peprotech.

\section{Cell culture}

HK-2 human kidney proximal tubular epithelial cell line was obtained from Shanghai Cell Bank of Chinese Academy of Science and was maintained in DMEM medium containing $10 \%$ fetal bovine serum and $1 \mathrm{X}$ PenicillinStreptomycin. Cells were cultured in $5 \% \mathrm{CO}_{2}$ incubator at $37^{\circ} \mathrm{C}$.

\section{Quantitative PCR (qPCR)}

Total RNA was extracted using Trizol method and then reverse transcribed into cDNA using reverse transcription kit from QIAGEN (Duesseldorf, Germany). QPCR was conducted using the following parameters: pre-denaturing at $95{ }^{\circ} \mathrm{C}$ for $10 \mathrm{~min}$; denaturing at $95{ }^{\circ} \mathrm{C}$ for $20 \mathrm{~s}$; annealing/extending at $61^{\circ} \mathrm{C}$ for $50 \mathrm{~s}$.

\section{Enzyme-linked Immunosorbent assay (ELISA)}

The level of complement C3 was evaluated using ELISA kit from Abcam (Cambridge, USA).

\section{Flow cytometry}

HK-2 cells were digested with trypsin for 2-3 min and centrifuged at $300 \mathrm{~g}$ for $5 \mathrm{~min}$. Cell pellets were resuspended in PBS containing PE-antihuman IL-2R $\beta$ (Biolegend, San Diego, USA) or isotype control (Biolegend). Staining was performed at $4{ }^{\circ} \mathrm{C}$ in dark for $20 \mathrm{~min}$. Flow cytometry was conducted on a FACS Calibur.

\section{Western blot}

Total cell lysates were subjected to sodium dodecyl sulphate-polyaacrylamide gel electrophoresis then transferred to PVDF membranes which were then blocked with $5 \%$ bovine serum albumin. The membranes were probed with appropriate primary antibodies and secondary antibodies. All antibodies were purchased from Cell Signaling Technology (USA).

\section{Statistical analysis}

Unpaired Student's $\mathrm{t}$ test was performed using SPSS 17.0 software. $P<0.05$ was considered statistically significant.

\section{RESULTS}

\section{COM upregulated expression of IL-2R $\beta$ in HK- 2 cells}

First, HK-2 cells were treated with COM to examine its effect on human proximal tubular epithelial cells. As shown in Figure 1, COM stimulation led to an increase in IL-2R $\beta$ mRNA level, peaking at $3 \mathrm{~h}$ and then progressively declined. Therefore, COM functions as an inducer of IL-2R $\beta$ expression in human proximal tubular epithelial cells. a

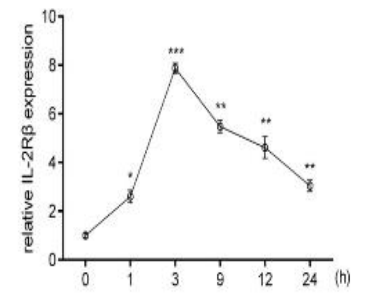

b

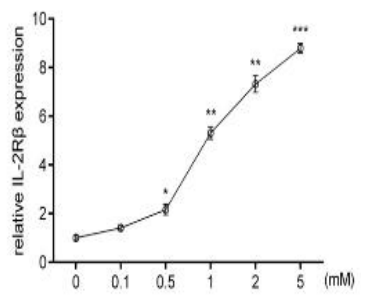

Figure 1: COM upregulates IL-2 $\beta$ expression in HK-2 cells. (a) HK-2 cells were treated with 2 mM COM for indicated time, the expression of IL-2 $\beta$ was evaluated by QPCR. (b) HK-2 cells were treated with different concentrations of COM for $2 \mathrm{~h}$, the expression of IL-2 $\beta$ was evaluated by QPCR. Data are mean \pm SD; * $p<$ $0.05 ;{ }^{* *} p<0.01 ;{ }^{* * *} p<0.01$ 
TFDS antagonizes COM-induced expressions of IL-2R $\beta$ in HK-2 cells

The effect of TFDS on COM-induced IL-2R $\beta$ expression was investigated. Although COM markedly upregulated mRNA level of IL-2R $\beta$ in HK-2 cells, concomitant treatment with TFDS significantly compromised the effect of COM, as evidenced by the results that the mRNA level of IL-2R $\beta$ in COM+TFDS group was reduced by 60 $\%$ compared to COM alone group (Figure 2 a). Next, the expression of IL-2R $\beta$ on cell surface was evaluated by flow cytometry. Similar to QPCR results, the IL-2R 3 -inducing role of COM was largely antagonized by TFDS. On the other hand, TFDS treatment did not affect the basal expression of IL-2R $\beta$ in the absence of COM (Figure $2 \mathrm{~b}$ and $\mathrm{c}$ ). Thus, TFDS functions as an antagonist of COM in terms of IL-2R $\beta$ expression. a

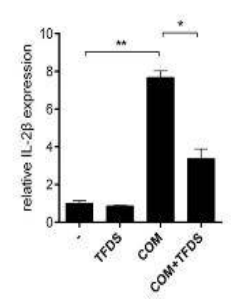

b

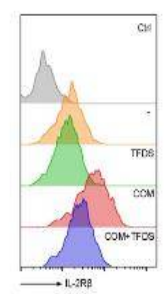

a

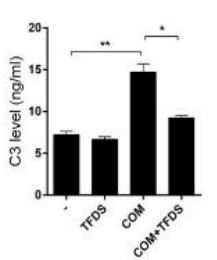

b

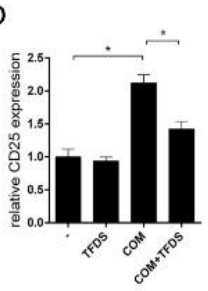

C

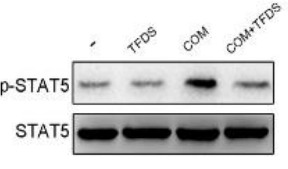

Figure 3: TFDS reduces the activation of IL-2 signaling in HK-2 cells HK-2 cells were pretreated with $2 \mathrm{mM}$ COM in the absence or presence of TFDS for 3 $\mathrm{h}$, followed by stimulation with $20 \mathrm{ng} / \mathrm{mL}$ IL-2, the level of complement C3 in culture supernatant was evaluated by ELISA (a), the level of CD25 was detected by QPCR (b), the phosphorylation of STAT5 was examined by western blot (c).Data are mean \pm $\mathrm{SD} ;{ }^{*} p<0.05,{ }^{* *} p<0.01$

\section{STAT3 signaling, but not p38 signaling is responsible for the TFDS-mediated downregulation of IL-2 $\beta$}

Since it is reported that COM induced strong activation of p38 signaling in human renal tubular epithelial cells, TFDS might downregulate IL-2 $\beta$ by suppressing p38 activation. Surprisingly, although pretreatment of $\mathrm{HK}-2$ cells with SB203580 (p38 inhibitor) partially prevented COM-induced upregulation of IL-2R 3 , TFDS showed a synergistic effect with SB203580 to cause a further reduction in IL-2R level. Besides p38, COM did not prominently increase the phosphorylation of ERK and JNK - the other two MAPKs (Figure 4 a). of IL-2 $\beta$. (a) HK-2 cells were treated with $2 \mathrm{mM} \mathrm{COM}$ in the absence or presence of TFDS for 3 hour, the expression of IL-2 $\beta$ was evaluated by QPCR. (b, c) HK-2 cells were treated with $2 \mathrm{mM}$ COM in the absence or presence of TFDS for 12 hour, surface expression of IL-2 $\beta$ was examined by flow cytometry. MFI = Mean Fluorescence Intensity. Representative plot (b) and statistical result (c) were shown. Data are mean \pm SD; ${ }^{*} p<0.05 ;{ }^{* *} p<0.01$

\section{TFDS decreases IL-2 responsiveness in COM- treated HK-2 cells}

To investigate if TFDS affects IL-2-induced gene expression, HK-2 cells were treated with COM in the absence or presence of TFDS, followed by IL-2 stimulation. As shown in Figure 3 a, COM pretreatment significantly increased the production of $\mathrm{C} 3$ as well as the production of CD25 in IL-2 stimulated HK-2 cells. However, in COM+TFSD group, IL-2-triggered C3 production and CD25 expression were significantly inhibited compared with COM group. In terms of IL-2 signaling, COM pretreatment led to enhanced STAT5 activation in IL-2 treated HK-2 cells, which was markedly suppressed by TFDS (Figure $3 \mathrm{~b}$ ). Thus, through preventing COMinduced IL-2 $\beta$ expression, TFDS reduced the responsiveness of HK-2 cells to IL-2 stimulation. a

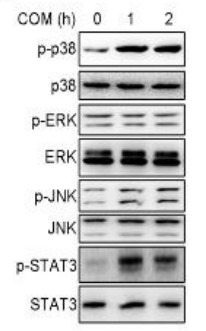

b

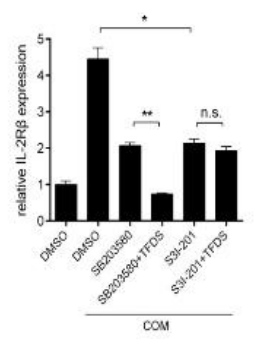

C

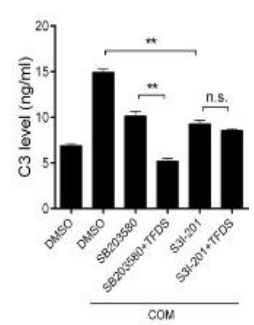

Figure 4: TFDS compromises the function of COM in a STAT3-dependent manner. (a) HK-2 cells were treated with $2 \mathrm{mM} \mathrm{COM}$, the phosphorylation of indicated proteins was evaluated by western blot. (b, c) HK-2 cells were pretreated with SB203580 or S3I201 or DMSO for $2 \mathrm{~h}$, followed by stimulation with COM or COM plus TFDS, (b) the level of IL-2R $\beta$ was evaluated by QPCR, (c) the level of complement C3 was detected by ELISA (c). Data are mean $\pm \mathrm{SD}$; ${ }^{*} p<$ $0.05,{ }^{* *} p<0.01$

Interestingly, the phosphorylation of STAT3 markedly enhanced by COM (Figure 4 a). Importantly, TFDS failed to downregulate IL-2RB expression when HK-2 cells were pretreated with S3I-201, a specific STAT3 inhibitor (Figure 4 b), 
suggesting that there was no synergistic effect between TFDS and STAT3 inhibition in preventing $\mathrm{C} 3$ production in $\mathrm{HK}-2$ cells. Furthermore, STAT3 inhibition, but not p38 inhibition abrogated the ability of TFDS to reduce IL-2 $\beta$ expression in COM-stimulated HK-2 cells. Therefore, TFDS antagonize COM-induced IL-2 $\beta$ expression primarily by inhibiting the activation of STAT3 signaling.

\section{IL-2R $\beta$ level correlates with the inflammatory status in kidney}

Finally, the possible clinical relevance of IL-2R $\beta$ to renal inflammation was investigated. By reanalyzing a dataset in GEO database, significant positive correlations between the level of IL-2R $\beta$ and the levels of complement C3, TNF- $\alpha$, and IL6 were observed in a renal cancer patient cohort (Figure 5). Thus, increased expression of IL-2R $\beta$ may be associated with enhanced renal inflammation.
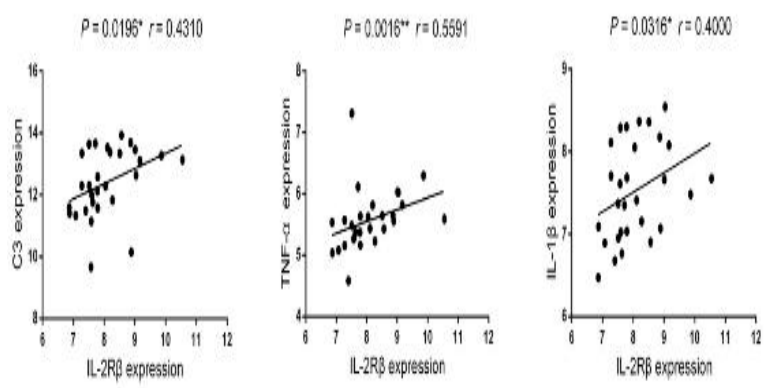

Figure 5: Positive correlation between the level of IL$2 \beta$ and the levels of complement C3/TNF- $\alpha /$ IL- 6 based on re-analyzing a GEO dataset (GDS4282)

\section{DISCUSSION}

As a traditional Chinese herb, the therapeutic effect of Desmodium styracifolium in alleviating renal diseases has been increasingly recognized, especially in the treatment of urinary calculi. It is reported that Desmodium styracifolium inhibited calcium oxalate stone formation through increasing urinary citrate excretion and reducing urinary calcium as an antioxidant [8]. Rodgers found that Desmodium styracifolium treatment resulted in the decreased particle size of precipitated crystals and the supersaturation of calcium oxalate in synthetic urine [9].

Although it has been reported that COM can induce p38 signaling in $\mathrm{HK}-2$ cells $[5,10]$, this study found that STAT3 signaling, but not p38 signaling was responsible for the effect of TFDS in antagonizing COM-induced IL-2b expression in human renal tubular epithelial cells. Previous studies have linked renal inflammation with IL-2 signaling $[6,7]$. In this work, TFDS was identified as an antagonist against COM-triggered IL-2 $\beta$ expression and complement C3 production, which was thought to be involved in the pathogenesis of renal inflammation.

Interleukin-2 receptor is composed of IL-2Ra, IL$2 \mathrm{R} \beta$ and IL-2Ry chain. Although IL-2 receptor is predominantly expressed on immune cells, especially T cells, Gerritsma JS have indicated that human proximal tubular epithelial cells can also express IL-2 receptor [6,7]. From functional perspective, IL-2 was reported to induce human proximal tubular epithelial cells to produce complement C3, which can lead to immune complex-associated renal inflammation [6]. Taken together, TFDS antagonizes multiple COM-induced detrimental effects on renal epithelial cells, while through distinct signaling mechanism.

\section{CONCLUSION}

This study identifies a novel function of total flavones of Desmodium styracifolium (TFDS) in suppressing IL-2 signaling. Due to its synergistic effect with p38 inhibition, TFDS may achieve higher efficacy when used in combination with p38 inhibitors.

\section{DECLARATIONS}

\section{Acknowledgement}

This study was supported by Traditional Chinese Medicine and Western Medicine Research of Tianjin Health and Family Planning Commission (no. 2015134), and Scientific Research Fund of Key Laboratory of Second Hospital of Tianjin Medical University (no. 2018ZDSYS11).

\section{Conflict of interest}

No conflict of interest is associated with this work.

\section{Contribution of authors}

We declare that this work was done by the researchers listed in this article. All liabilities related with the content of this article will be borne by the authors. Haijie Xie and Rui Yang designed all the experiments and revised the manuscript. Yong $\mathrm{Xu}$ and Chunyu Liu performed the experiments, wrote the paper. Haijie Xie and Rui Yang contributed equally to this work; Yong $\mathrm{Xu}$ and Chunyu Liu contributed equally to this work. 


\section{Open Access}

This is an Open Access article that uses a funding model which does not charge readers or their institutions for access and distributed under the terms of the Creative Commons Attribution License (http://creativecommons.org/licenses/by/ 4.0) and the Budapest Open Access Initiative (http://www.budapestopenaccessinitiative.org/rea d), which permit unrestricted use, distribution, and reproduction in any medium, provided the original work is properly credited.

\section{REFERENCES}

1. Edvardsson VO, Indridason OS, Haraldsson G, Kjartansson $O$, Palsson R. Temporal trends in the incidence of kidney stone disease. Kidney Int 2013; 83(1): 146-152.

2. Tiselius HG. Epidemiology and medical management of stone disease. BJU Int 2003; 91(8): 758-767.

3. Gan QZ, Sun $X Y$, Bhadja $P$, Yao $X Q$, Ouyang JM. Reinjury risk of nano-calcium oxalate monohydrate and calcium oxalate dihydrate crystals on injured renal epithelial cells: aggravation of crystal adhesion and aggregation. Int J Nanomed 2016; 11: 2839-2854.

4. Mittal A, Tandon S, Singla SK, Tandon C. In vitro inhibition of calcium oxalate crystallization and crystal adherence to renal tubular epithelial cells by Terminalia arjuna. Urolithiasis 2016; 44(2): 117-125.

5. Xie H, Li J, Gao H, Wang J, Li C, Xu Y, LiU C. Total flavone of Desmodium styracifolium relieved apoptosis and autophagy of COM-induced HK-2 cells by regulating KIM-1 via p38/MAPK pathway. Mol Cell Biochem 2018; 442(1-2): 169-175.

6. Brooimans RA, Stegmann AP, van Dorp $W T$, van der Ark $A A$, van der Woude FJ, van Es LA, Daha MR. Interleukin 2 mediates stimulation of complement $C 3$ biosynthesis in human proximal tubular epithelial cells. $J$ Clin Invest 1991; 88(2): 379-384.

7. Gerritsma JS, Gerritsen $A F$, van Kooten $C$, van Es $L A$, Daha MR. Expression of the IL-2 receptor on human renal proximal tubular epithelial cells. J Am Soc Nephrol 1997; 8(10): 1510-1516.

8. Mi J, Duan J, Zhang J, Lu J, Wang H, Wang Z. Evaluation of antiurolithic effect and the possible mechanisms of Desmodium styracifolium and Pyrrosiae petiolosa in rats. Urol Res 2012; 40(2): 151-161.

9. Rodgers AL, Webber D, Ramsout R, Gohel MD. Herbal preparations affect the kinetic factors of calcium oxalate crystallization in synthetic urine: implications for kidney stone therapy. Urolithiasis 2014; 42(3): 221-225.

10. Schindler JF, Monahan JB, Smith WG. p38 pathway kinases as anti-inflammatory drug targets. $J$ Dent Res 2007; 86(9): 800-811. 